Otterbein University

Digital Commons @ Otterbein

2008-2009 Season

Productions 2001-2010

4-30-2009

\title{
One Flew Over the Cuckoo's Nest
}

Otterbein University Theatre and Dance Department

Follow this and additional works at: https://digitalcommons.otterbein.edu/production_2008-2009

Part of the Acting Commons, Dance Commons, and the Theatre History Commons

\section{Recommended Citation}

Otterbein University Theatre and Dance Department, "One Flew Over the Cuckoo's Nest" (2009).

2008-2009 Season. 2.

https://digitalcommons.otterbein.edu/production_2008-2009/2

This Book is brought to you for free and open access by the Productions 2001-2010 at Digital Commons @ Otterbein. It has been accepted for inclusion in 2008-2009 Season by an authorized administrator of Digital Commons @ Otterbein. For more information, please contact digitalcommons07@otterbein.edu. 



\section{OTTERBEIN COLLEGE \\ DEPARTMENT OF THEATRE AND DANCE \\ Presents}

\section{One Flew Over the Cuckoo's Nest By \\ DALE WASSERMAN}

Adapted from the novel by

KEN KESEY

Directed by

DENNIS ROMER

Set Design
STEPHANIE GERCKENS

Sound Design

DAVE MEAD
Costume Design

REBECCA WHITE

Fight Choreography by

DREW COTTON

Stage Managed by

ALLIE VAN NIMAN

Lighting Design

DAVID KERR 


\section{cast}

\section{The Patients}

Chief Bromden. Eric Folks

Dale Harding

Billy Bibbit. Cory Michael Smith

Scanlon Nathan Keen

Cheswick Jackson Hille

Martini. A.J. Smitrovich

Ruckly Jihad Milhem

Randle P. McMurphy Josh Mahaffey The Staff

Aide Warren Drew Cotton Aide Williams Luke Scroggins Dr. Spivey Trenton I. Weaver

Nurse Ratched Lauren J. Wertz Nurse Flinn. Caroline Whetzel Aide Turkle Kolby Kindle

\section{Others}

Candy Starr Christina Scariano Sandra Jonelle Browne

\section{setting}

The Pacific Northwest, fall of 1962

The Action takes place in the day room of the State Mental Ward

There will be one 15-minute Intermission.

\section{special thanks}

Mt. Carmel St. Ann's Hospital

Chile Verde, Sawmill Rd.

Trudy Mason, Otterbein College Nursing Department 
Artistic Advisor

Rob Johnson

Audience Services Director

Elizabeth Saltzgiver

Production Manager

Meghan Gauger

Movement Coach

Melinda Murphy

Speech \& Dialect Coach

Melissa Lusher

Technical Director.

Scenic Studio Supervisor Greg Bell

Costume Shop Supervisor.

Assistant Director.

Richard Uhrick

Marcia Hain

Assistant Costume Designer

Seth Cotterman

Assistant Lighting Designer

Renee Scott

Assistant Stage Managers

Jon Seiler

Assistant Technical Director....

Samantha Fremer \& Julia Rice

Master Carpenter/ Deck Chief.

Colin Murray

Master Painter/ Costume Shopper

Laura Fickley

Props Master

Alex Raabe

Draper

Becky Woodruff

First Hands

Sandy Vojta

Wardrobe Master.

Michelle Leibrock \& Lauren Williams

Master Electrician

Micah Harvey

Assistant Master Electrician .

Michelle Leibrock

Light Board Operator

Jack Denzinger

Sound Designer

Reece Arthur

Sound Operator

Dave Mead

Box Office Manager.

Alyssa Pence

House Manager. Sarah Waits

Seth Cotterman

\section{Scenic Studio Assistants}

\section{Doug Sarmir}

Jack Denzinger

Jon Seiler

James McSweeney

Ali Flynn

\section{Set and Props Running Crew}

Berlyn Drabik

Becky Woodruff

Jake Robinson

\section{Light \& Sound Assistants}

\begin{abstract}
Laura Fickley
\end{abstract}
Colin Murray

David Kerr

Jon Seiler

\section{Electrics Participation Crew}

Shane Zalcburg

Stanzi Davis

Lauren Friednash

Jamie Ferguson
Patrick Shafer

Alexandria Flynn

Samantha Fremer
Scenic Studio Participation Crew

Berlyn Drabik

Becky Woodruff

Jake Robinson

James McSweeney

Scott Drayer

Ellie Testa

Heavenee Chandler

Leea Ayers

Michael Weingand

Reece Arthur

\section{Costume Shop Assistants}

Berlyn Drabik

Jamie Ferguson

Wes Jenkins

Michelle Leibrock

Lauren Williams

\section{Wardrobe Running Crew}

Adam Schalter Abbey Bay

\section{Box Office Assistants}

Rebecca Bell

Travis Harty

Jordan Martin

Kari Sims

Liz Shivener
Becky Woodruff 


\section{program notes}

One Flew Over the Cuckoo's Nest is a staged adaptation of Ken Kesey's well known novel about his personal experiences while participating in a government study on drugs such as LSD. Several of the characters are based on actual people Kesey encountered during this trial as well as time he spent working in an asylum. There are strong references to the experimental treatments used in psychiatric institutions during the 1960 's including electroshock therapy, lobotomies, and medications which produced severe side effects. In the 1950 's, it is estimated that 1 in 3 families would have someone admitted into a psychiatric institution. Patients not only included the mentally ill, but also wards of the state, orphans, chronically ill persons, and elderly who no one wished to care for. Instituionalizing became a modern day witch hunt, with families and the government admitting anyone they did not view as "normal."

-Julia Rice, Assistant Stage Manager

One flew Over the Cuckoo's Nest isn't just about patients in a psychiatric ward, it is about something much deeper. It is much more about the question of normalcy. In today's world we often find ourselves labeling others "crazy". When we walk down the street and see someone talking to themselves, it's easy for us to say, "Wow, that's not normal, he must be insane." In reality, however, we have all had an imaginary friend and we have all been so caught up in something that literal conversations occur in our heads.

As we go through today's headlines and read about a woman who has given birth to eight children it is at first, "miraculous," but as soon as we discover that she is already a single mother of six and has little income, we are quick to change the label to "outrageous" and to question the woman's sanity. There are many examples in our daily routines that blur the line between normalcy and instability.

So what is normal? By definition normal means "serving an established standard by conforming to a common type." If that is true then wouldn't we all be considered a little abnormal? Would it really be fair and honest to say you are just as common as the person sitting next to you?

When watching One Flew Over the Cuckoo's Nest, we have to ask ourselves if the patients in the play really are that different from us. They may display strange twitches or neuroses, but can we always promise a proper display of emotion? In the play, for instance, Nurse Ratched can be viewed as a nurturing and caring woman who wants nothing but for her patients to be cured, or she can be a terrifying and controlling character that demonstrates an unnatural urge for domination. Another character, Billy, is institutionalized because of tremendous issues of living up to his mother's standards.

Which character do you classify as "crazy"? Both have the same thoughts, fears, and anxieties that you and I share, and both exhibit extreme ways of coping with those emotions. The difference in the play is that one is in the mental ward, and the other is in charge of the mental ward. McMurphy just may be right in saying, "They're a lot crazier outside". 


\section{profiles}

Dennis Romer (Director) has directed many productions for the Otterbein College Department of Theatre and Dance. Some favorite projects include Who's Afraid of Virginia Woolf, The Scene, And Baby Makes Seven, Jesus Christ Superstar, Death of a Salesman, Stop Kiss, Father Joy, A Little Night Music, Romeo and Juliet, Phantom and The Laramie Project. Dennis is enjoying an outstanding collaborative process with the cast, designers, and crew. He sends special thanks to his Assistant Director, Seth, and the Stage Management Staff, Allie, Julia, and Sam.

Stephanie Gerckens (Scenic Designer) is pleased to return to her alma mater, Otterbein College, where she previously designed Violet, Longevity Abbreviated, Blood Brothers, Steel Magnolias, Antigravity, and Moonchildren (co-production with CATCO). Her design credits at CATCO include Boston Marriage, Escanaba in Da Moonlight, Lobby Hero, Murder in Green Meadows, Taste of Sunrise, and Drawer Boy. She was awarded Best Design for her work on Drawer Boy by the Central Ohio 'Theatre Critics' Circle. Phoenix Theatre's productions of Miss Piggle-Wiggle and Many Moons featured her scenic designs. She has also designed scenery for Ohio Wesleyan University, Weathervane Playhouse, Miami Valley Dinner Theatre (La Comedia), Chicago's Remains Theatre, Griffin Theatre and Pegasus Players and Circa-21 in Rock Island, Illinois. She spent two seasons at Actors Theatre of Louisville as Resident Assistant Scene Designer and Charge Scenic Artist. Stephanie has painted for theatre, television, and film with clients including The Oprah Winfrey Show, Carnegie Hall, The Massachusetts Museum of Science, Arena Stage, BalletMet, Opera Columbus, the independent feature film Lawn Dogs (Lead Painter) and professional scene shops in Boston, Washington D.C. and Chicago.

Rebecca White (Costume Designer) is Otterbein's faculty costume designer. Rebecca teaches courses in Costume Design, Technology, Makeup, and an Integrative Studies course. Rebecca holds an MFA from the University of Minnesota, and a BS from the University of Wisconsin, LaCrosse. Originally from Minnesota, Rebecca has done design work for The Penumbra Theatre Company, Park Square Theatre, Theatre l'Homme Dieu, and the Minnesota Centennial Showboat. Here at Otterbein, Rebecca has designed for Peter Pan, Julius Caesar, An Absolute Turkey, and Proof. She will also design the costumes for Don't Talk to the Actors and The Last Night of Ballhoo during the 2009 Otterbein Summer Theatre season.

Dave Kerr (Lighting Designer) is a junior at Otterbein College majoring in Theatre Design/ Tech. This will be his 15 th show and second lighting design at Otterbein. His previous positions included Lighting Designer on Dance 2009: To Each His, Own Master Electrician on And Baby Makes Seven, The Caucasian Chalk Circle, and Smokey Joe's Café, Assistant Technical Director on An Absolute Turkey and Assistant Lighting Designer on Dance 2008: Gotta Dance and Smokey Joe's Café. David is very excited to be working with everyone on this show and he would like to thank his parents for their continuing encouragement and support. He would also like to thank the faculty with their help and support on his first full lighting design at Otterbein and everyone else who has helped him along the way.

Dave Mead (Sound Designer \& Consultant) has worked on national touring productions of The Fantasticles, and The Great Radio City Music Hall Spectacular as an audio designer for theatrical productions. Regionally, Mead has worked as a sound designer for Players Theatre, and the Contemporary American Theatre Company. Mead has served as a sound designer and sound consultant for the Otterbein College Theatre Department for the past seventeen years and over 46 different productions. Notable Otterbein productions include Into The Woods, 


\section{profiles}

Evita, Cabaret, To Kill a Mockingbird, Jesus Christ Superstar and West Side Story. In 2008 Mead stepped down as CEO of Live Technologies, Inc. after founding and leading the company for twenty-three years. During that period of time the company grew from a staff of five to over eighty associates and sales exceeding nine million dollars. Mead is currently working as a business development associate for Live Technologies.

Allie van Niman (Stage Manager) is stage managing her first show at Otterbein College, and she couldn't have worked with a better cast and crewl Allie is a sophomore BA, and she has been an Assistant Stage Manager on Julius Caesar and Dance Concert 2008 before this. She wants to thank her amazing ASMs, her sisters of Epsilon Kappa Tau, and her mom for keeping her from joining the crazies on stage!

Marcia Hain (Costume Shop Supervisor) has been a member of the Otterbein Theatre Tech Staff since 1989. She runs the costume shop full time and has also designed for the productions of Dance 2008: Encore!, Urinetown, The Spitfire Grill, Private Lives, Hello, Dolly!, Harvey, Dance 2006: Street Fest, You're A Good Man Charlie Brown, Dance 2005: Passions, The Ugly Duckling + 2, The Music Man, Schoolhouse Rock, Live!, The Mystery of Edwin Drood, A Guy, A Girl and Gershwin, Blithe Spirit, The Secret Garden, Oklahoma, Hay Fever, Dance 2000, Pinocchio, How The Other Half Loves, Once Upon A Mattress, 1776, A Few Good Men, and Sherlock's Last Case. She also served as Associate Designer for Phantom. Ms. Hain has an extensive background in Home Economics, as well as commercial costuming and free-lance design and construction.

Melissa Lusher (Speech \& Dialect Coach) teaches speech, dialects, and theatre history in the Department of Theatre and Dance at Otterbein College, where she is also the resident speech/dialects coach for all productions. In addition, she regularly serves as a guest dialect coach at area universities and theatre companies. Recent guest coaching posts include Noises Off at Ohio Wesleyan University, Homebody/Kabul at Denison University, and Hay Fever at the Dublin Abbey Theatre. Melissa holds an M.F.A. in Acting from the combined program of Carnegie Mellon University and the Moscow Art Theatre in Russia and a B.F.A. in Acting from Carnegie Mellon. She was a founding company member of the American Studio Theatre in New York City and also served as the company's resident voice and speech coach. Melissa performs regularly with Actors' Theatre Company (Goneril in King Lear, Maria in Twelfth Night, and multiple roles in Measure for Measure). Other favorite roles include Marina in Volodya (LaMama E.T.C.), Margaret in Richard III and Emilia in Othello (AST), Clytemnestra in The Greeks (Moscow Art Theatre), and the title role in Miss Julie (CMU). Melissa is a member of the Voice and Speech Trainers Association (VASTA).

Melinda Murphy (Movement Coach) teaches Alexander Technique and Feldenkrais Method $(B)$ in the Otterbein Theatre and Dance Department, with application to movement, voice, characterization, singing, and dance. Melinda is one of the few teachers trained in both methods; she combines them in her private practice in Columbus, and in classes and seminars for performing artists at other Ohio colleges. Since coming to Otterbein, she also trained to teach Fitzmaurice Voice work for its specialized tools for improving the voice and breath. Melinda has coached Otterbein productions since the turn of the century. She has also coached equestrians, figure skaters, musicians, and competitive barbershop quartets and choruses including the two-time international gold medalist Southern Gateway Chorus. 


\section{profiles}

Rich Uhrick (Scene Shop Supervisor) Before his return to his alma mater, he worked in Regional Theatres across the Midwest and New England including Actors Theatre of Louisville, Merrimack Repertory Theatre, New American Theatre, Kansas City Repertory Theatre (at UMKC), and The Court Theatre in Chicago. He received his Master's in Theatre Technology from UMKC in 1997. He now lives in Columbus with his wife, Lisa, and his son Michael. They work with Ohio Pug Rescue, to provide abandoned or surrendered dogs foster homes. In addition, they are active foster parents for the Bair Foundation. Rich is also a published poet and newsletter editor for the Columbus Bonsai Society and the Palatines to America: Ohio chapter genealogical society.

Jonelle Browne (Sandra) is a senior BFA Acting major wrapping up her last quarter here at Otterbein. She just spent all of winter quarter in NY on an internship with NBC and loved every minute of it. Before that, Jonelle was in the classroom project, The Scene fall quarter. Some other past productions here at Otterbein include While We Were Bowling, Batting Cage, Proof, Indian Blood, and Peter Pan. She is very much looking forward to performing this summer in The Last Night of Ballyboo as part of the summer season. She'd like to thank Dennis for giving her a fun scene for the quarter; Melinda for the drunk chocolate; Rebecca for stuffing her into her pink pants; her parents for making the trek to support her as the drunk earthy wench; her favorite twitch, Tina, for the dressing up, the character study, and for the bravery to let it all out; and her amazing class of 2009. "Here we go, y'all Love you."

Seth Cotterman (Assistan Director/ House Manager) is a sophomore BA Theatre and Public Relations double major. Working on Cuckoo's Nest has been intense and rewarding. Thanks to Dennis, cast and crew, for making this a great experience. "Thanks Mom, for keeping me grounded and focused."

Drew Cotton (Aide Warren/ Fight Choreographer) is a junior Musical Theater major and is extremely excited to be involved in such a wonderful experience with the greatest group of people. He wants to thank Dennis for being so wonderful to work with and for giving him the opportunity to continue his fight choreography work here at Otterbein College. (He also choreographed the fighting for Julius Cesar and An Absolute Turkey. He wants to thank Eric, Steve, and Lauren for their trust in his choreography and Nate for being a rock to lean on. He also wants to thank his parents for their love; his brothers for being his inspiration; Barbara for keeping him happy; and the class of '10 for their sarcasm. "Death Is Temporary, Love is Forever" -SW.

Steve Czarnecki (Randel P. McMurphy) is a senior Musical Theatre major from Rochester Hills Michigan. Steve is thrilled to be part of such a powerful piece with usch an incredible ensemble. Previous credits include Antony Julius Caesar, Lockstock in Urinetonn. Steve was also lucky enough to work at the Utah Shakesperian Festival. Steve would like to thank the circus, $\mathrm{Liz}$, the Shivener's and John and Jan for all their support! Enjoy the show!

Eric Folks (Chief Bromden) is a junior Acting major from Fort Wayne, IN. Previous Otterbein credits include An Absolute Turkey, The Scene, Civil Disobedience, The Caucasian Chalk Circle, Urinetown, and Hello Dolly! He would like to thank Dennis, the cast, and crew for a wonderful process; the ever magnificent BFA Class of 2010 for being awesome; his parents Kay and Ken, brother Nathan, and Harvey for their constant love and support; and his brothers at Pi Beta Sigma. 


\section{profiles}

jamantha Fremer (Assistant Stage Manager) is a freshman Design/Tech major emphasizing n Stage Management. Past productions include: An Absolute Turkey and Julius Caesar at Oterbein and Barefoot in the Park and To Kill a Mockingbird at the Culver Academies. Working on his show has been an incredible experience! Samantha would like to thank Allie, Julia, Seth, som, and the freshman DTs.

ackson Hille (Scanlon) is just tickled pink to be in his first Otterbein Campus Center Theater erformance. His previous Otterbein credits include Victor, the trouser-less bellhop, in $A n$ 4bsolute Turkey; Slightly Soiled, eldest of the Lost Boys, in Peter Pan; and a Soldier/Commoner n Julius Caesar. Jackson sends many thanks to Dennis for making this show so insanely fun to se a part of; his mother, Kim, for putting up with him; and (as always) the brothers of Pi Beta igma for absolutely nothing. Enjoy the show! OFA

Vathan Keen (Billy Bibbit) is a junior BFA Musical Theatre major with a concentration in Jance from Birmingham, MI. Nathan is thrilled to have the chance to perform in this amazng production. Previous Otterbein Theatre credits include Barnaby (Hello Dolly.), Tiny Tom Urinetown: The Musical), Indian (Peter Pan), Lucius (Julius Caesar), and a featured Dancer (Encore, Jotta Dance!, To Each His Own). Favorite roles include The Little Boy (Ragtime original cast of he National Tour), and Gavroche (Les Misérables National Tour and Broadway). Thank you o Dennis Romer for giving him this amazing opportunity and for putting up this absolutely pectacular show; and thanks to the entire cast and crew for making this one of the most pecial and unforgettable experiences of his life. He also would like to thank his roommates ind Drew for putting up with him and keeping him sane; and the amazingly talented class of 2010. He sends special thanks to his family for everything, and to Cassie for all her love and iupport. "I love you." *Strength \& Honor*

Kolby Kindle (Aide Turkle) is a junior BFA Musical Theatre major from Oklahoma City, OK, ind is thrilled to be a part of such a powerful show. Kolby's Otterbein credits include, Hello Dolly! (Rudolph), Urinetown (Robby the Stockfish), Peter Pan (Smee), Smokey Joe's Cafe (Singer/ Jancer), An Absolute Turkey (Pontagnac) and Dance Concerts: Encore (2007) and Gotta Dance '2008). Kolby has performed with The Lyric Theatre of Oklahoma, The Pollard Theatre 'Guthrie, OK) and West Virginia Public Theatre's productions of Dreamgirls (Tiny Joe Dixon I Ensemble) and The Wizard of $\mathrm{O}_{z}$ (Cowardly Lion). Other credits include Jesus Christ Superstar, Chess, Once on this Island, Little Shop of Horrors, Fiddler on the Roof, and Music Man. Kolby would ike to thank God, his family and his friends for all of their love and support. He would also ike to thank Dennis for his "cool" direction. Kolby sends MUCH LUV to the cast of this zreat show and to the class of 2010 !

Josh Mahaffey (Ruckly) is thrilled almost to the point of insanity that he has the opportunity to work on this show. His previous Otterbein credits include An Absolute Turkey, Julius Caesar, Indian Blood, Peter Pan and The Caucasian Chalk Circle. Some of his other favorite productions include Rosencrantz and Guildenstern are Dead, A Midsummer Night's Dream, and The Madwoman of Chaillot. Josh would like to thank Dennis, this wonderful cast, the ever-talented class of 2010, his family and friends, the BBTC, his lady Megan and his Brothers at Pi Beta Sigma. Enjoy the showl

Jihad Milhem (Martini) is a junior Acting major from Columbus. This is Jihad's 6th produc- 


\section{profiles}

tion here at Otterbein; others include Proof, Julius Caesar, and The Batting Cage. Jihad would like to thank Dennis for giving him the chance to tackle this challenging role; the amazing ensemble of actors that allow him to get lost with them; and the fantastic crew for making the day room become a living, breathing machine. He would also like to give thanks to his family and friends (especially his mom); his brothers at Pi Beta Sigma; the ever-fierce class of 2010; and wish all the best to the class of 2009. "This is for all the guys who got caught in an Air Raid."

Julia Rice is a sophomore BA Theatre major from Coshocton, OH. She is thrilled to be the Assistant Stage Manager on this show. She was previously the ASM on The Scene and Miss Witherspoon and the House Manager for Smokéy Joe's Café and Dance 2009: To Each His Own. Julia thanks the cast and crew for all of their hard work in making this production possible. She sends special thanks to Allie and Sam for all of their hard work and enthusiasm. (7:02?) Also, thanks to my family and Ben for all of their love and support and to the One who never leaves nor forsakes.

Christina Scariano (Candy Starr) is a junior Musical Theatre major from Billings, MT. Past Otterbein credits include: An Absolute Turkey (Lucienne), The Scene (Clea), Urinetown (Hope), Civil Disobedience (Actress), Proof (Catherine), and My Way. Tina would like to thank the cast and crew, especially her big earthy wench Sandra for helping her to become the best twitch she can be. She sends her love to the housemates and best wishes to all the seniors!

Luke Scroggins (Aide Williams) is a sophomore Acting major from the Republic of Texas. He enjoys all rodeo activities and events, most especially the pony toss. Luke is thrilled to be working with this awesomely talented cast and crew on such a crazy and incredible journey. Past OC credits include Peter Pan, Julius Caesar, and Savage/Love. Luke sends a big fat "thank you" to his parents, Rick and Jess - but definitely not to Pi Beta Sigma; those guys are losers. "Its okay Honey, they're a lot crazier outside"

A.J. Smitrovich (Cheswick) is a senior BFA Acting major from Los Angeles, CA. He recently completed an internship at April Webster Casting, working on the casting for Criminal Minds and the new pilot, Washington Field. He also made his television debut late last month on Criminal Minds. He wil return to LA to find an agent and continue working. He would like to thank his parents, Bill and Shaw, and sister Maya for their undying love and support. A.J. would also like to thank his wonderful girlfriend Courtney, his extremely successful class of '09 and his brothers at Pi Beta Sigma. "OFA."

Trenton I. Weaver (Dr. Spivey) is a sophomore Musical Theatre major from Gahanna, Ohio and is thrilled to be a part of such an incredible team. Previous Otterbein credits include An Absolute Turkey (Pinchard), Smokey Joe's Café (Ensemble), and The Caucasian Chalke Circle (the Fat Prince). He would like to thank Dennis for believing in him, the cast and crew for being brilliant, Melinda for her magic, the class of 2011 for being... something, Jen for whom words do not do justice, and his family for all of their love and support.

Lauren J. Wertz (Nurse Ratched) After driving 757 miles southeast with her Dad in 2007, Lauren now finds herself as a Sophomore BFA Musical Theatre major on the Otterbein stage! She hails from Minnesota where there are in fact more than 10,000 lakes and where the phrase "you-betcha" honestly isn't said all too often. She was thrilled to be a part of this 


\section{profiles}

awesome production and was extremely excited to take on its challenges. Previous Otterbein credits include Madame Pinchard, An Absolute Turkey, and Caius Ligarius, Julius Caesar. "Many thanks to Sandy and Rebecca, my fellow cast members, and Dennis. To my family at home: my heart and thanks for your never-ending support. Justin, Dan, and Kristin: I love you and miss you all; can't wait for what's to come! And to Everyone: enjoy the show!"

Caroline Whetzel (Nurse Flinn) is a junior BFA Acting major from Louisville, KY, and is thrilled to be a part of One Flew Over the Cuckoo's Nest. Most recently Caroline has been seen as Caesar's Servant in Julius Caesar, and Michael in Peter Pan. Caroline would like to thank the cast and crew for all of their hard work and dedication to the production. She would like to thank her family for all of their love and support.; Mark for all of his constant encouragement; the fabulous girls of 1D for being such wonderful friends and her home away from home; and of course, the crazy fierce class of 2010. "I love you all! "

Becky Woodruff (Props Master) is a freshman Theatre major. Previous Otterbein Theatre credits include Assistant Prop Master and Publicity Assistant for The Scene. She was an intern for the upcoming independent film Take Me Home, written and directed by Sam Jaeger. Becky will also be Prop Master for the Otterbein Summer Theatre shows this year. She would like to thank Doreen, Asami, Janie, Richard, Danica, Joel, Greg, Stephanie, Dennis, her family, and most of all, Will.

Produced by special arrangement with SAMUEL FRENCH, INC. 



\section{OTterbein College Theatre}

Latecomer's Policy - The House Manager may seat latecomers only during times which minimize disruption of the performance. The management accepts no responsibility for inconvenience to latecomers and can make no adjustment because of it.

Fire Notice - The exit indicated by a red light nearest to your seat is the shortest route to the street. In the event of fire or other emergency please do not run - walk to that exit.

Cameras and Recording Devices - The use of recording equipment and the taking of photographs during the performance are strictly prohibited.

Restrooms and Telephones - The restrooms and telephones are located underneath the lobby.

Assisted Hearing Devices are available for Cowan Hall productions. Please request one at the Box Office.

\section{Administrative Office}

614/823-1657

Monday-Friday 8:30-5:00

\section{Box Office}

614/823-1109

Monday-Friday 1:00-4:30 


\section{Humanity replaces usual villainy}

By Margaret Quamme

FOR THE COLUMBUS DISPATCH

One Flew Over the

Cuckoo's Nest isn't quite a classic: It tips toward melodrama rather than tragedy.

It's a feminist nightmare in which the forces of good are represented by a punchdrunk, sexually aggressive guy and the forces of evil by a woman with power.

So it's a pleasant surprise that, under Dennis Romer's nuanced direction, the recently opened Otterbein College production finds complexity under the fablelike surface and humanity in what were originally the most unconditionally villainous roles.

Dale Wasserman's adaptation of Ken Kesey's 1962 cult novel explores what happens when rabble-rouser Randle P. McMurphy (Steve Czarnecki) enters the fearful world of a men's ward at a mental institution whose inhabitants seem to have suffered permanent damage from encounters with controlling wives and mothers.

Randle, who has gotten himself committed simply to avoid work at a prison camp, immediately enters into conflict with icy Nurse Ratched (Lauren Wertz) and the battle for the souls of the other inmates occupies the rest of the play.

Underscoring Romer's control as a director is the way the production steers deftly away from imitating the well-known film adaptation of the novel - particularly the key characters created by Jack Nicholson and Louise Fletcher.

Czarnecki's McMurphy has a commanding physical

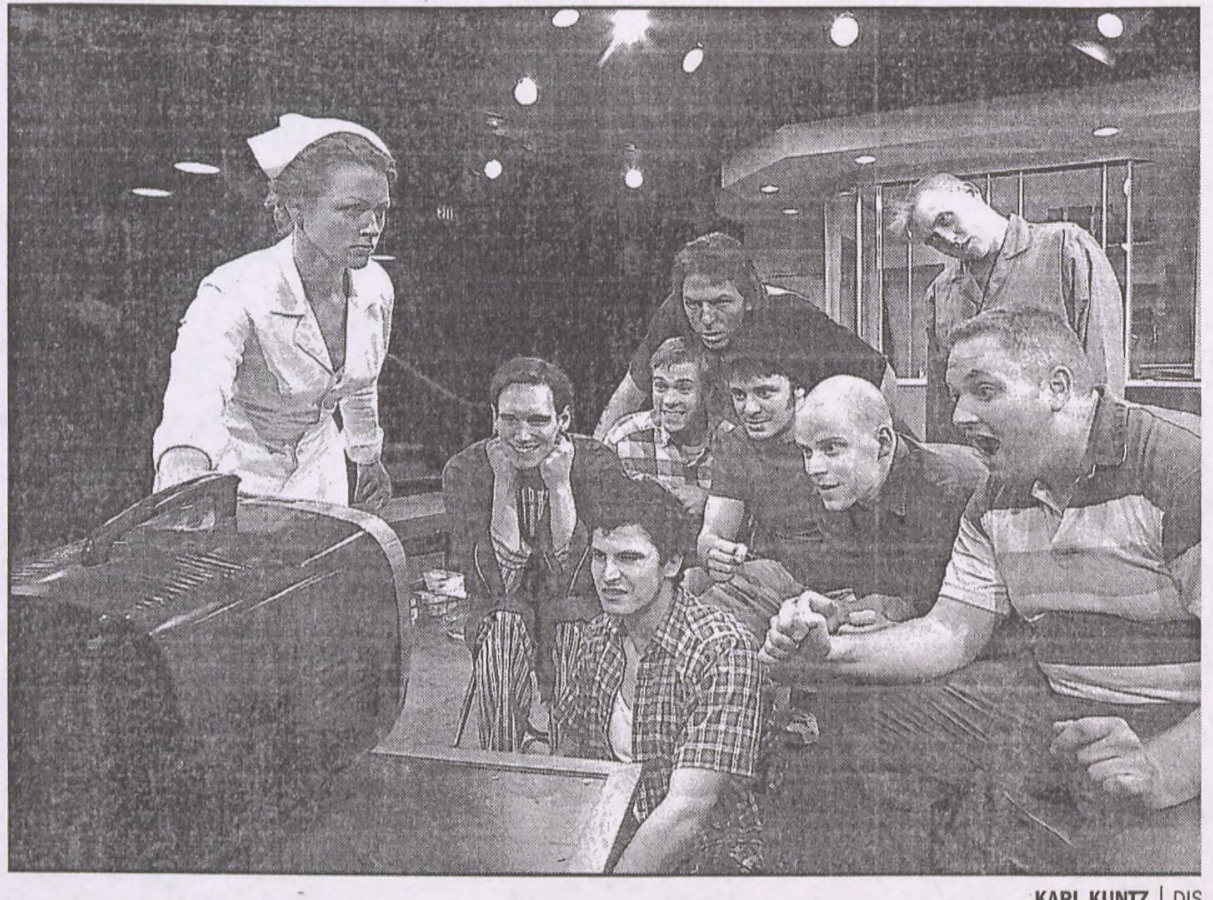

KARL KUNTZ | DIS

Nurse Ratched (Lauren Wertz) and patients, with McMurphy (Steve Czarnecki) in the (

Otterbein College will present One Flew Over the Cuckoo's Nest at 8 p.m. today, Saturday, next Friday and May 9 in the Campus Center Theatre, 100 W. Home St., Westerville. Tickets cost \$15. Call 614-823-1109 or visit www.otterbein.edu/ theatre.

presence, but his mind doesn't keep pace with his blustering mouth: He makes conscious choices only after he's already in action.

Wertz is particularly wellcast as Nurse Ratched, and her subtle performance reveals how a few small changes in a scene's tone can affect a play's influence.

Although she has the firm smile of someone conducting a permanent tea party, this nurse isn't oversize or evil: Her actions might yield devastating results, but she clearly acts out of what she thinks are the best of intentions.

The rest of the large cast performs ably in the ensemble.

The standouts include Eric Folks as the quietly stirring Chief Bromden, the narrator whose inner dialogue is interspersed with the outer action; Corey Michael Smith as the bright and prickly Dale Harding, the leader of the group before McMurphy's arrival; Josh Mahaffey as the surprisingly moving Ruckly, the inmate who for most of the play stands self-crucified against a wall; and Kolby Kindle as the refreshingly dry Turkle, the prison ai least dedicated to his jo

The production plays the comedy in the story without ignoring its pat and, at the Wednesday view performance for $\mathrm{n}$ bers of the campus con nity, the audience responded with enthusj to its many sparks of humor.

Much about the scrip remains a problem: The constant and explicit re ences to McMurphy as Christ figure, in particu become grating.

Yet Romer's thoughtf production finds grace places where the origin found only horror, mak the story more powerfu expanding its vision of human possibility.
Subnline Subscriptian MANAGER

Headed out of town for a w Temporarily stop deliver @ dispatch.com/service 
